\title{
Energy Management of Microgrids for Smart Cities: A Review
}

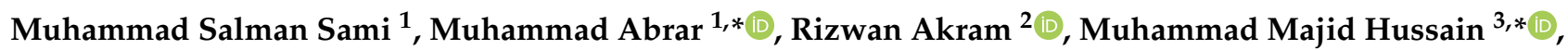 \\ Mian Hammad Nazir ${ }^{3}$, Muhammad Saad Khan ${ }^{1}$ and Safdar Raza ${ }^{4}$ \\ 1 Department of Electrical Engineering, Bahauddin Zakariya University, Multan 66000, Pakistan; \\ salman.samee999@gmail.com (M.S.S.); saadkhan@bzu.edu.pk (M.S.K.) \\ 2 Department of Electrical Engineering, College of Engineering, Qassim University, \\ Qassim 51452, Saudi Arabia; rizwanakram75@qec.edu.sa \\ 3 Faculty of Computing, Engineering and Sciences, University of South Wales, Cardiff CF37 1DL, UK; \\ hammad.nazir@southwales.ac.uk \\ 4 Department of Electrical Engineering, NFC Institute of Engineering and Technology (NFC-IET), \\ Multan 60000, Pakistan; safdar.raza@nfciet.edu.pk \\ * Correspondence: mabrar@bzu.edu.pk (M.A.); muhammad.hussain@southwales.ac.uk (M.M.H.)
}

check for updates

Citation: Sami, M.S.; Abra, M.; Akram, R.; Hussain, M.M.; Nazir, M.H.; Khan, M.S.; Raza, S. Energy Management of Microgrids for Smart Cities: A Review. Energies 2021, 14, 5976. https://doi.org/10.3390/ en14185976

Academic Editor: Pierluigi Siano

Received: 6 August 2021

Accepted: 16 September 2021

Published: 20 September 2021

Publisher's Note: MDPI stays neutral with regard to jurisdictional claims in published maps and institutional affiliations.

Copyright: (c) 2021 by the authors. Licensee MDPI, Basel, Switzerland. This article is an open access article distributed under the terms and conditions of the Creative Commons Attribution (CC BY) license (https:// creativecommons.org/licenses/by/ $4.0 /)$.

\begin{abstract}
Electric power reliability is one of the most important factors in the social and economic evolution of a smart city, whereas the key factors to make a city smart are smart energy sources and intelligent electricity networks. The development of cost-effective microgrids with the added functionality of energy storage and backup generation plans has resulted from the combined impact of high energy demands from consumers and environmental concerns, which push for minimizing the energy imbalance, reducing energy losses and $\mathrm{CO}_{2}$ emissions, and improving the overall security and reliability of a power system. It is now possible to tackle the problem of growing consumer load by utilizing the recent developments in modern types of renewable energy resources (RES) and current technology. These energy alternatives do not emit greenhouse gases (GHG) like fossil fuels do, and so help to mitigate climate change. They also have in socioeconomic advantages due to long-term sustainability. Variability and intermittency are the main drawbacks of renewable energy resources (RES), which affect the consistency of electric supply. Thus, utilizing multiple optimization approaches, the energy management system determines the optimum solution for renewable energy resources (RES) and transfers it to the microgrid. Microgrids maintain the continuity of power delivery, according to the energy management system settings. In a microgrid, an energy management system (EMS) is used to decrease the system's expenses and adverse consequences. As a result, a variety of strategies and approaches are employed in the development of an efficient energy management system. This article is intended to provide a comprehensive overview of a range of technologies and techniques, and their solutions, for managing the drawbacks of renewable energy supplies, such as variability and load fluctuations, while still matching energy demands for their integration in the microgrids of smart cities.
\end{abstract}

Keywords: microgrids; energy management; smart city; renewable energy sources; photo voltaic; energy storage; energy management system

\section{Introduction}

The terminology "smart city" refers to more efficient, equitable, and adaptable cities which will be created using socioeconomic, environmental, and technological systems [1]. In terms of power, the essential aspects of a smart city are a reliable electricity supply from renewable energy sources (RES) and the application of energy efficient techniques throughout the system; i.e., at least $80 \%$ of the city's structures should be energy efficient. Smartness is defined as the intelligent integration of all infrastructural and socioeconomic activities that pave the way for a brighter future, not simply technologically. We believe that only by intelligent use of human, financial, and technical resources, and in consideration of 
environmental, demographic, social, infrastructural, and economic issues, can this ideal future can be realized.

Renewable energy resources (RES) such as wind, biomass, solar, tidal energy, and hydropower are examples of RES that can ameliorate the problem of the increasing greenhouse effect while emitting zero pollutants into the atmosphere [2-5]. RES have the potential to make a major contribution to the mitigation of fossil fuels and global climate change [6]. Renewable energy (RE) should be cost-effective, and come from clean energy source [7] which is also environmentally friendly [8]. In many papers ([9] and the references included there), several scholars explored the common concepts of renewable energy resources (RES), distributed generation (DG), and microgrids. To satisfy the ever-increasing energy demands, power plants are being built near major consumption points. Energy supply is becoming much more competitive, resulting in lower prices $[10,11]$.

In terms of the power paradigm, smart energy and stable electricity networks are some of the most important aspects of smart cities; in fact, electricity grids and information and communication networks are the two technological features that primarily characterize smart cities. Smart energy and power networks are enabling microgrids to be integrated into smart cities, which not only facilitate the integration of renewable energy sources but also enable new energy-related value-added services [12]. A microgrid is defined as a collection of loads, energy storage facilities, and small-scale generating systems [13]. A microgrid is an electrically bound portion of a distribution network that collects locally in order to form a self-sufficient energy system. Distributed generating sources, energy storage devices, and controlled loads must all be integrated to produce a self-sufficient energy system $[14,15]$. Microgrids may provide a dependable source of electricity in remote regions where the development or expansion of electrical grids is physically and/or economically difficult. Although these systems are unable to make use of the main grid, they serve as valuable test beds for developing suitable control functions capable of maintaining a reliable supply of electricity [16-19]. Hybrid energy systems (HES) are frequently used to provide electrical power for a variety of uses, such as residences or farm land in outlying areas where there is no grid extension [20]. Hybrid energy systems offer high reliability and lower costs as compared to systems that have only one energy source [21].

Microgrids offer real-time energy management. Each has its own communication system that is necessary for managing the energy between generation and demand [22]. Microgrids play a major role in the transition of urban infrastructure into a smart city. Water, transportation, and other infrastructures rely on distribution grids for fundamental services; microgrids, equipped with modern information and communication technology, are grids that are suitable for smart cities. Microgrids operate in one of the two modes: isolation and grid $[23,24]$. As illustrated in Figure 1, microgrids can be classified by the types of energy source they use, such as renewable, nonrenewable, or hybrid.

Renewable energy resources (RES) such as wind and solar do not produce constant amounts of electricity. As a result, predicting and maintaining the generation from these resources is extremely challenging, which may result in fluctuations in the continuous power supply. The microgrid's reliability and the preservation of the energy supplydemand balance are both important. The latter problem becomes more prevalent in stand-alone mode when there are few sources available to satisfy demand [25-27]. 


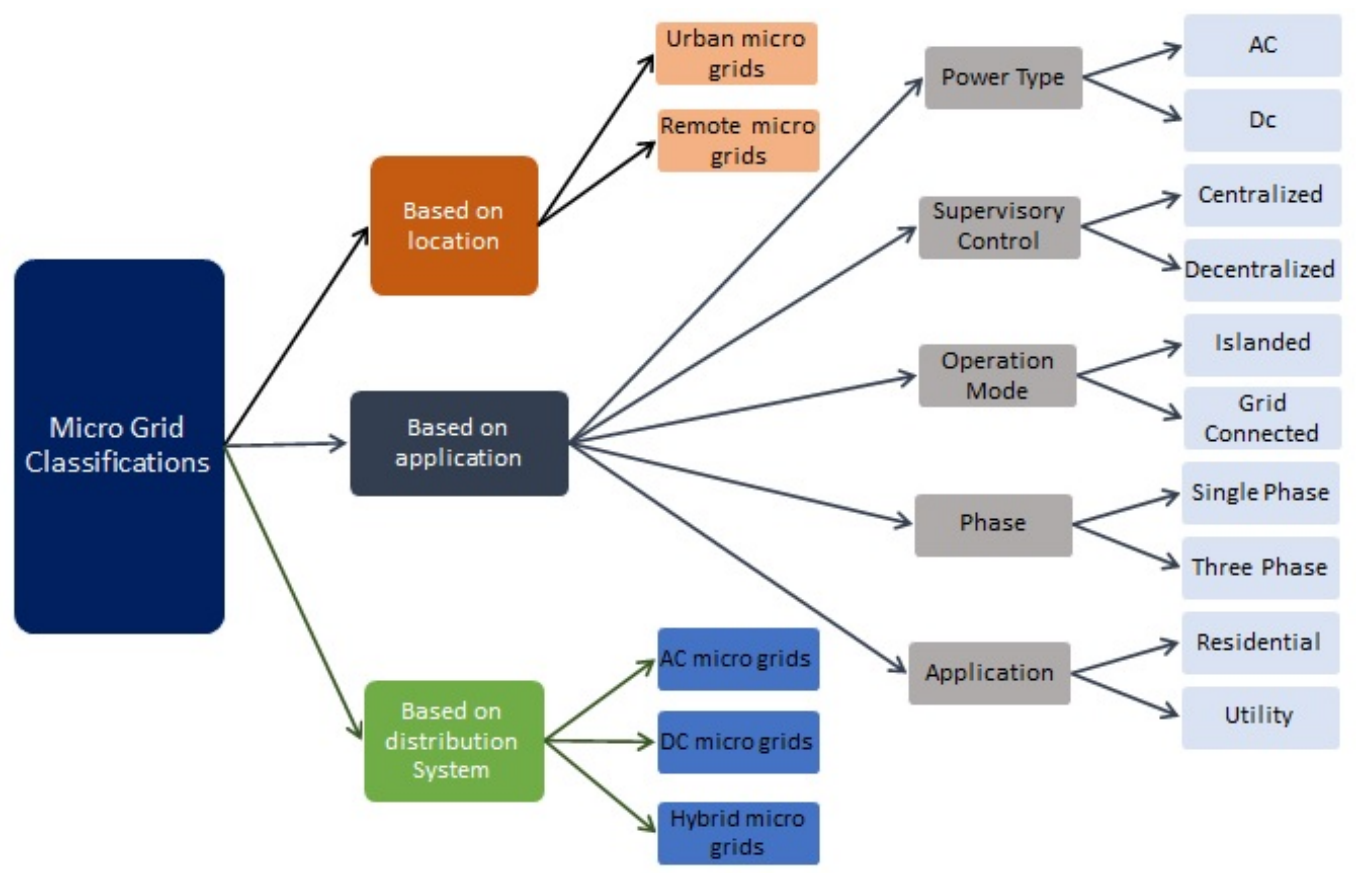

Figure 1. Classification of MGs.

\section{Microgrid EMS-Based Network}

Microgrids frequently experience trouble with supplying and consuming energy due to the shortcomings of renewable energy sources [28]. To deal with energy management systems, microgrids have their own communication networks (EMS). The energy management system provides optimum solutions to microgrids, which are developed from various mathematical techniques to discover optimal solutions. Using to these approaches, the microgrid can reduce the uncertainty and load varying issues of renewable energy resources [18]. The EMS of a microgrid operates in two modes, centralized and decentralized, ensuring that generation and load are matched [29-31]. Microgrids are also categorized based on their modes of operation, which include power type, supervisory control, phase, and application, as illustrated in Figure 1.

The intelligent communication module in the microgrids EMS uses the best decision making strategies, including human-machine interface modules (HMI), DERs for load forecasting, and a supervisory control and data acquisition module, which delivers the best decision and tries to increase the revenue of the microgrid by using communication network [32-35].

However, while the initial installation costs of renewable energy-based plants are higher than those of conventional plants, the maintenance and operating costs are lower and will continue to fall as technology advances. As the behavior of renewable sources is usually intermittent, it is better to employ several resources when they are accessible. Hybridization of renewable resources enhances the efficiency, reliability, and economics of the power system. These hybrid MGs, as illustrated in Figure 2, can be used as stand-alone units, grid-connected units, or in conjunction with traditional units [36-38].

The intermittent nature of an RES/microgrid is due to the fact that loads are connected to solar and wind energy sources rather than the grid, and these sources have a major influence on loads. When there is a shortage in these sources due to environmental factors, the loads stay connected without any supply. Frequency fluctuations, voltage fluctuations, and harmonic distortion are the primary concerns with power quality. The system will become unstable as a result of voltage fluctuations caused by changes in irradiation levels, which will have a direct impact on the solar and wing-based stand-alone systems' reliability. The same is applicable in the wind example, where variations in wind speed have an impact 
on the whole hybrid system. Accurate forecasting and scheduling are necessary to minimize these effects [39-42].

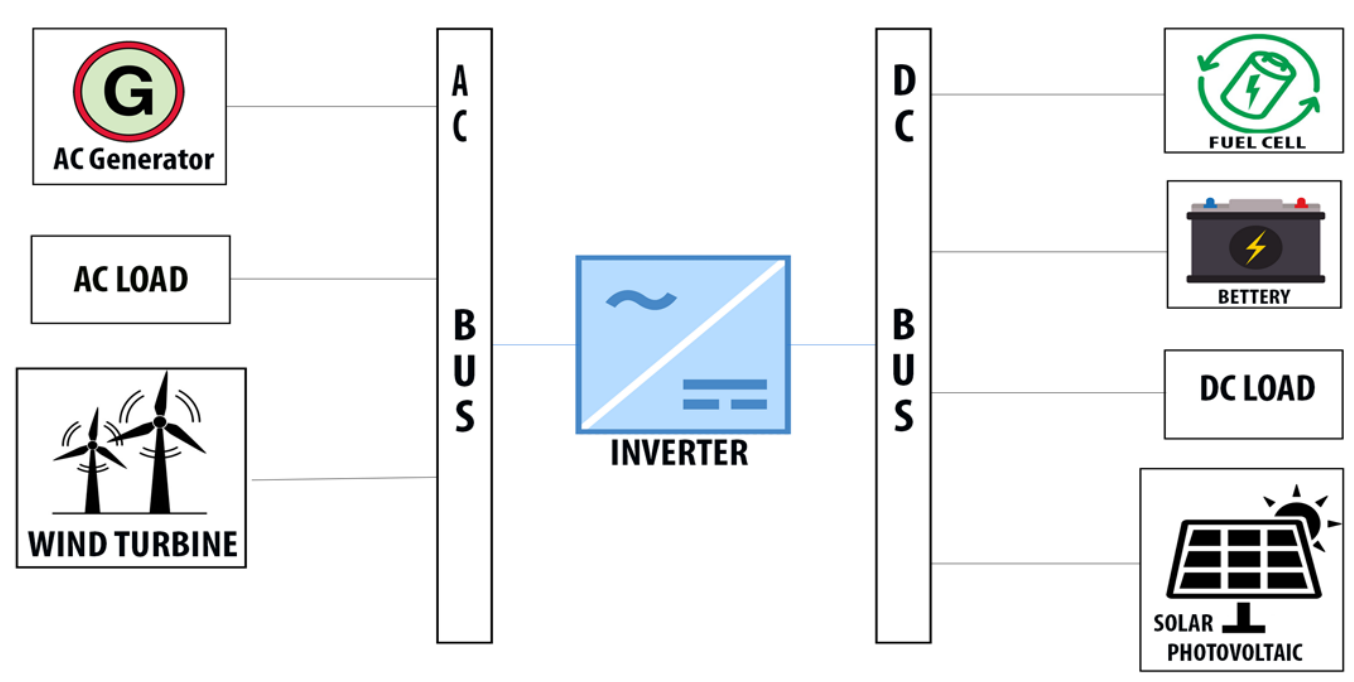

Figure 2. Hybrid microgrid.

Several scholars have addressed these energy management techniques utilizing various solution methodologies in order to accomplish optimal and effective MG operation. The subsections that follow provide a comprehensive critical study of these techniques and solutions.

\section{Classical Methods of EMS}

\subsection{Energy Management by Linear/Non Linear}

E. Dursun and O. Kilic [43] investigated the behaviors of three methods on a standalone hybrid system, including PV/wind/PEMFC, where PV and wind were considered primary sources and PEMFC was considered a backup source. The author's main objective in this work was to increase the efficiency of the fuel cell (FC) and provide a continuous power supply in the hybrid system with no fluctuations. The researcher used established power management techniques to assess battery efficiency, taking into account the battery state-of-charge (SOC) and surplus power from the primary source in a Matlab/Simulink control algorithm (wind and PV).

J. Ahmad et al. [44] offered a cost-effective energy management technique based on mixed integer linear programming. Researchers are looking at the influences of hybrid systems on capital and operational expenses. One can reduce load peaks by keeping an eye on this kind of generation's intermittency and instability. The cost function is computed using linear programming, and the size of the microgrid is optimized using HOMER software through simulation. An energetic and economic analysis of three distinct solar assisted heat pump (SAHP) systems using the best operational approach was published in [45]. Three distinct types of SAHPs, and solar collectors and battery sizes, were discussed in this article. The mixed-integer linear programming (MILP) method lowered the heating system's running costs, and numerical analysis was carried out using TRNSYS and Refprop 9.1 software.

Moazeni and J. Khazaei [46] examined the convergence time and reduced the cost function of the water-energy microgrid by using two techniques, mixed-integer nonlinear programming (MINLP) and MILP. MILP was utilized in the first approach to minimize the cost function and achieve optimality in the MINLP formulation. In the second technique, MILP was used to simulate the nonlinear behavior of the cost function using MATLAB software. In [47], three alternative techniques were presented to investigate the performance of a hybrid system that included solar panels (PV) and battery storage devices. TRNSYS software was used for performance testing, and size was determined manually. 
HOGA (also known as iHOGA) and HOMER software were used for genetic algorithm optimization, and the state of charge of the battery and the pressure in the hydrogen tank were studied.

M. Nemati, M. Braun [48] introduced two algorithms used for microgrid work scheduling, unit commitment and economic dispatch. The latter is a superior genetic algorithm (GA), and the former is an MILP that was enhanced. This study also introduced a unique technique for dealing with MILP restriction and a new lithium battery aging model. To evaluate the microgrid model and compare it to others in different situations, GA and MILP optimizers were used. In [49], the mix-mode energy management technique (MMEMS) was presented, which optimizes the cost-effectiveness microgrid operation and provides the optimal battery sizing for economic microgrid operation. The author solved economic dispatch problems by using three techniques, on/off mode, continuous mode, power-sharing mode. Linear programming (LP) was used to solve energy management problems such as powersharing and continuous modes, whereas MILP was used to solve on/off mode (MILP). The size problem of the battery was solved by the particle swarm optimization technique.

Anglani and Braun [50] presented an economically optimized energy management system (OEMs) for a microgrid which minimized the fuel consumption of a remote temporary military base (FOB) featuring diesel generators. The linear programming method was used to optimize the cost-effectiveness of a diesel generator fuel consumption. The suggested semi-continuous optimization model was solved using two approaches. Only one generator was operational in the first approach, and both generators were operational in the second, but only one generator output was used at a time. Moreover, the rain flow method was used to deal with battery sizing and charging/discharging between operational and capital costs.

Helal and Hanna [51] examined the energy management system that deals with the optimal scheduling of a hybrid AC/DC microgrid for remote areas. The energy management problems were formulated by the MINLP and the goal was to keep the daily operating costs as low as possible. All the EMS simulations were done via MATLAB where the optimizer was modeled via the GAMS environment. For hybrid microgrids in remote locations, [52] employed a two-stage stochastic optimization method. The size and uncertainty problems in a hybrid microgrid were solved using LP and MILP optimization. The MILP optimization yielded the most stable system, but the LP model yielded the most cost-effective system. Python was used to implement the optimization algorithms. A summary of recent studies of EMS based linear/nonlinear has been compiled in Table 1.

Table 1. Summary of recent studies of EMS based on linear/nonlinear programming.

\begin{tabular}{|c|c|c|c|}
\hline Reference & System Configuration & EMS Approach & Remarks \\
\hline [43] & PV/wind/PEMFC & $\begin{array}{c}\text { MILP via } \\
\text { MATLAB/Simulink }\end{array}$ & $\begin{array}{l}\text { To improve the fuel cell membrane's efficiency and } \\
\text { ensure a continuous energy flow in the hybrid } \\
\text { system, three strategies were examined in this paper. }\end{array}$ \\
\hline$[44]$ & Hybrid Micro grid & MILP via HOMER & $\begin{array}{l}\text { Author Minimized operational cost, and reduce } \\
\text { intermittency, instability, and load peaks of the } \\
\text { hybrid system. }\end{array}$ \\
\hline$[45]$ & $\begin{array}{l}\text { SAHP/PV / Thermal }(\mathrm{PV} / \mathrm{T}) \\
\text { collectors }\end{array}$ & $\begin{array}{l}\text { MILP via TRNSYS and } \\
\text { Refprop } 9.1\end{array}$ & $\begin{array}{c}\text { The researcher reduces the operational cost of the } \\
\text { Heating system, battery sizes, and study SAHP } \\
\text { operational strategy. }\end{array}$ \\
\hline [46] & Water Energy micro gird & $\begin{array}{l}\text { MILP and MINLP via } \\
\text { MATLAB }\end{array}$ & $\begin{array}{c}\text { The researcher applied two techniques and analyzed } \\
\text { the convergence time, cost function, and nonlinear } \\
\text { behavior of the model of a micro grid. }\end{array}$ \\
\hline [47] & PV / battery storage systems & $\begin{array}{l}\text { MILP and GA via TRNSYS } \\
\text { and HOMER }\end{array}$ & $\begin{array}{c}\text { Three strategies were proposed in this paper to } \\
\text { analyze the performance testing and SOC of } \\
\text { the battery. }\end{array}$ \\
\hline
\end{tabular}


Table 1. Cont.

\begin{tabular}{|c|c|c|c|}
\hline Reference & System Configuration & EMS Approach & Remarks \\
\hline [48] & $\begin{array}{l}\text { Multi cell grid } \\
\text { structure/CEMS }\end{array}$ & MILP and GA via MATLAB & $\begin{array}{l}\text { Two algorithms were proposed in this paper for } \\
\text { scheduling the unit commitment and economic } \\
\text { dispatch of micro grids. }\end{array}$ \\
\hline [49] & Grid-tied MG & $\begin{array}{l}\text { LP/MILP/PSO via } \\
\text { MATLAB }\end{array}$ & $\begin{array}{c}\text { The author analyzed the ON/OFF mode, continuous } \\
\text { mode, power-sharing mode of grid-tied micro grid, } \\
\text { and optimized the BES system. }\end{array}$ \\
\hline$[50]$ & FOB/BESS/PV & $\begin{array}{l}\text { MILP / Rain flow method } \\
\text { via MATLAB }\end{array}$ & $\begin{array}{c}\text { The author minimized the fuel consumption of diesel } \\
\text { generators and analyzed battery } \\
\text { charging/discharging between operational and } \\
\text { capital costs. }\end{array}$ \\
\hline [51] & Hybrid AC/MG & $\begin{array}{l}\text { MINLP via MATLAB } \\
\text { an GAMS }\end{array}$ & $\begin{array}{l}\text { The author presented a technique to deal with } \\
\text { optimal scheduling of hybrid micro grids. }\end{array}$ \\
\hline [52] & Isolated hybrid MGs & LP/MILP via python & $\begin{array}{l}\text { Two-stage stochastic optimization technique is } \\
\text { presented in this paper to solve sizing and } \\
\text { uncertainty problems in the hybrid micro grids. }\end{array}$ \\
\hline
\end{tabular}

\subsection{Energy Management Based on Rule Based and Dynamic Programming}

Merabet and Ahmed [53] presented a real-time energy management system of a hybrid microgrid using wind, solar, and battery. An online rule-based optimization technique is introduced to manage the switching operation among battery charging/discharging, off mode of the PV system, and load shedding. In a laboratory based hybrid microgrid experiment, power converters and control algorithms provide efficient and stable operation of EM between different sources in microgrids. Testing and control of microgrids are performed in MATLAB/Simulink, and real-time monitoring is performed by integration with RT-LAB.

M. Jafari and Z. Malekjamshidi [54] provided an economic strategy for an energy management system that incorporates a set of PV panels, a fuel cell panel, and a battery in both grid-connected and off-grid modes of a hybrid microgrid. Dynamic programming (DP) deals with the off-line optimization, and real-time monitoring is done by the rule-based controller, which ensures the optimal control of power flow. MATLAB's graphical user interface was used to keep track of and record data from the proposed energy management system in both scenarios, sunny and cloudy PV generation. While [55] offered optimal distributed generation scheduling to accomplish economic and environmental output, and ensure power security and stability in microgrids. In this study, two primary objectives were considered: economic and environmental objectives. As a result, this work considered multi-objective and multi-parametric optimization, and the dynamic performance of battery problems. Multi-parametric dynamic programming was used to optimize the energy management of microgrids. Simulation results were used to assess the model's efficiency.

Shuai and Fang [56] proposed two optimal operations in microgrids for real-time energy management. The first one is MINLP in which Ac power flow and battery storage are considered. The second one is approximate dynamic programming (ADP), which was formulated for optimization problems. The microgrids are connected to the grid. The solution of the Bellman equation determines sequential decisions. The optimization algorithm's efficiency was tested numerically using a microgrid benchmark and MATLAB. In [28], they focused the economical energy management of real-time microgrids while considering load fluctuations and power flow constraints. The Markov decision process (MDP) was formulated for real-time scheduling. To achieve optimal real-time scheduling, approximate dynamic programming (ADP) with a recurrent neural network (RNN) was developed. To understand the optimal value function, an iterative method approximate policy iteration (API) is used. The simulation model was analyzed in MATLAB R2015a. A 
summary of recent studies of EMS based on rule/dynamic programming is presented in Table 2.

Table 2. Summary of recent studies of EMS based on rule/dynamic programming.

\begin{tabular}{|c|c|c|c|}
\hline Reference & System Configuration & EMS Approach & Remarks \\
\hline [53] & wind/solar/battery & $\begin{array}{l}\text { Rule-based via } \\
\text { MAT- } \\
\text { LAB/Simulink/ } \\
\text { RT-LAB }\end{array}$ & $\begin{array}{l}\text { Author analyzed the switching } \\
\text { operation among battery } \\
\text { charging/discharging, off mode } \\
\text { of the PV system, and load } \\
\text { shedding of micro grids. }\end{array}$ \\
\hline$[54]$ & PV/FC/Battery & $\begin{array}{c}\text { DP/Rule-based via } \\
\text { MATLAB }\end{array}$ & $\begin{array}{l}\text { Author proposed an optimal EM } \\
\text { plan between off-grid and } \\
\text { grid-connected modes of micro } \\
\text { grids }\end{array}$ \\
\hline [55] & Hybrid MG & $\begin{array}{l}\text { Multi-parameter } \\
\text { dynamic } \\
\text { programming }\end{array}$ & $\begin{array}{l}\text { Optimal scheduling of DGs and } \\
\text { battery sizing problems are } \\
\text { considered in this paper }\end{array}$ \\
\hline [56] & Hybrid MG & $\begin{array}{l}\text { ADP/MINLP via } \\
\text { MATLAB }\end{array}$ & $\begin{array}{c}\text { In this paper, real time EM of MG } \\
\text { is proposed }\end{array}$ \\
\hline [28] & Hybrid MG & $\begin{array}{c}\mathrm{MDP} / \mathrm{ADP} / \mathrm{RNN} \\
\text { via MATLAB }\end{array}$ & $\begin{array}{l}\text { The researcher proposed } \\
\text { algorithms were derived to } \\
\text { achieve optimal real time } \\
\text { scheduling }\end{array}$ \\
\hline
\end{tabular}

\section{Meta-Heuristic Approaches of EMS \\ Energy Management Based Particle Swarm Optimization}

The PSO algorithm's basic elements are the swarm's population and the number of particles in the swarm. The PSO introduces a search space where these particles move according to a set of basic formulae. These particles define their own best positions and the swarm's overall best position in order to discover the optimal position in relation to each other. They arrive to control the growth of the swarm after they have discovered their optimal places. The process of determining the optimal place is ongoing, although it is not precise [57-61]. The population of birds is depicted in Figure 3, with birds seeking for food in a search area.

C. Li, X. Jia, and Y. Zhou [62] presented an energy management technique to keep the load curve stable in microgrids. Three types of multi-agent models were investigated in this paper: the underlying case, the demand response case, and energy storage case. The authors described a solution to solve these three factors and compare the results by applying the metaheuristic approach that is particle swarm optimization. Moreover, the author combined two algorithms, adaptive search and the chaotic search method, to enhance the PSO to an ACPSO algorithm, which reduces the number of iterations using a Jade and MATLAB environment. In [63] was an improvement of the energy management of the solar-diesel hybrid generator. Two cases of optimum scheduling were investigated in this study. When the load was large in the first scenario, the amount of additional solar energy had to be raised in proportion. When the load was low in the second scenario, the diesel generator's efficiency had to be considered. The author created a multi-objective optimization model, which he solved numerically using the PSO optimization approach. 


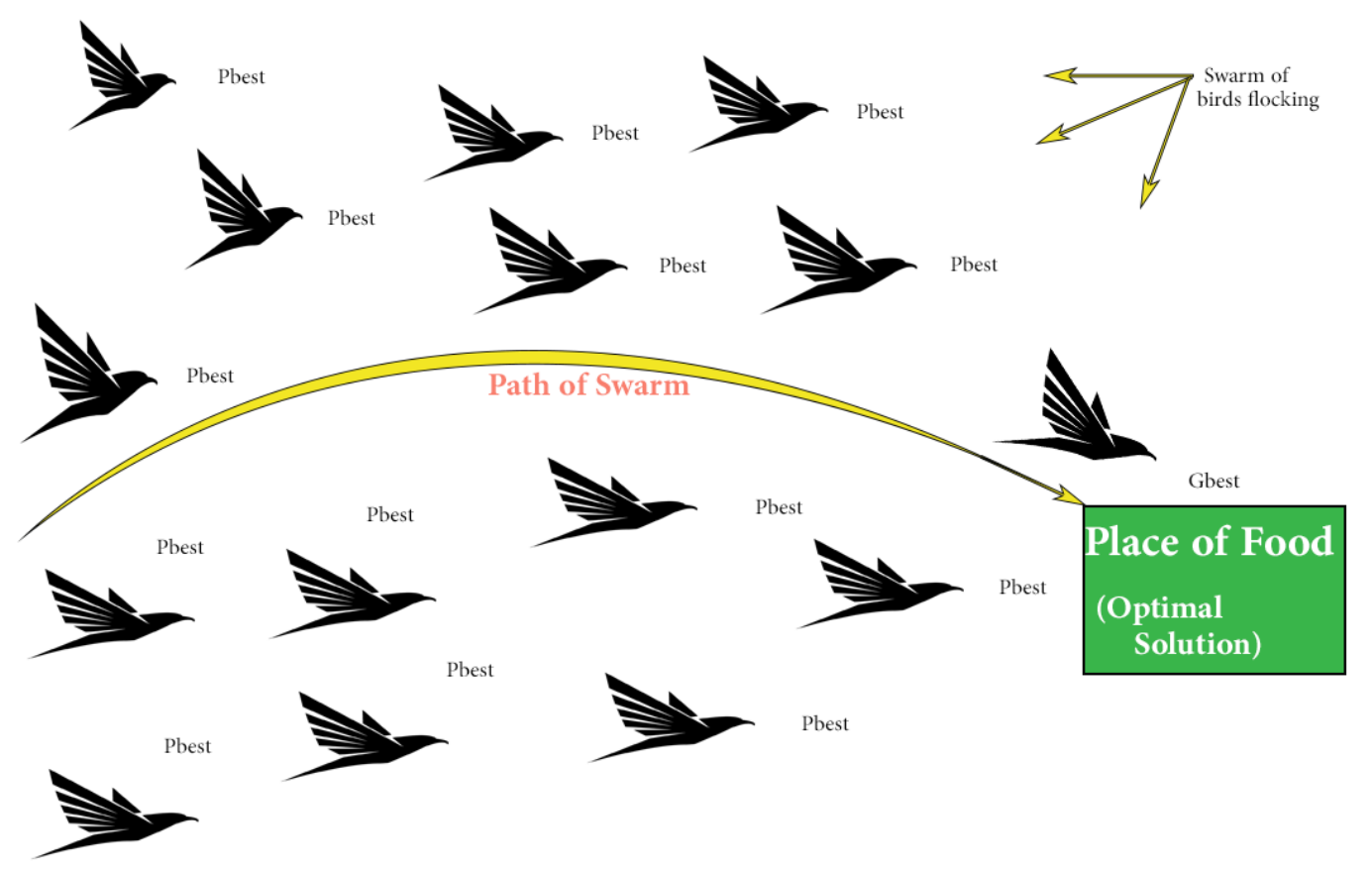

Figure 3. Particle swarm optimization.

Hossain and Pota [64] calculated real-time energy management and electricity pricing by using the meta-heuristic algorithm. In this article, a modified PSO was developed to cope with the cost function and battery charging and discharging activities. The cost function graph may be modified by the need for real-time energy management in the community using MATLAB, as shown in the simulation results. In [65], a multi-period power flow approach based on successive approximations (SA) and an energy management methodology that follows the master salve strategy to cope with the particle swarm optimization (PSO) were employed in tandem to determine the optimal solution of a Battery storage system (BSS). Simultaneous quadratic programming was used in MATLAB software to evaluate simulations.

T. Kerdphol and Y. Qudaih [66] proposed an EMS to prevent MGs from instability and system breakdown during extreme situations. The author derived PSO from the integration of demand response (DR) and evaluated the optimal size of the BESS system to boost the system's performance, safety, and stability. For the real-time energy management of standalone microgrids, particle swarm optimization (PSO) has been employed in [67,68]. A summary of recent studies of EMS based on rule/dynamic programming is presented in Table 2.

\section{Energy Management Based on Genetic Algorithm}

Charles Darwin's idea of natural evolution influenced genetic algorithms [69-71]. As part of the algorithm, the most appropriate individuals are selected for reproduction in order to create children in the following generation. The genetic algorithm is based on two main operations, crossover and mutation. Crossover shows the probability of a pair of parents mating [72-76]. The basic process of GA is shown in Figure 4.

Genetic algorithms (GAs) are one of the most popular population-based heuristic optimization approaches, and they are utilized to address a wide range of issues [41]. The ESS economic strategy and an actual matrix formatted GA-based smart EMS technique were developed by C. Chen and S. Duan [33] for grid-connected MGs. When it comes to predicting solar energy, the NN model is utilized. The net present cost of the ESS during its lifespan is considerably increased by an economic model based on its capital, operating, and maintenance expenses, and revenue from energy arbitration. Smart EMS includes 
generator bids, storage bids, and electricity market revenue to reduce the MG's operating costs while satisfying the energy balance limitations and physical constraints of the DERs.

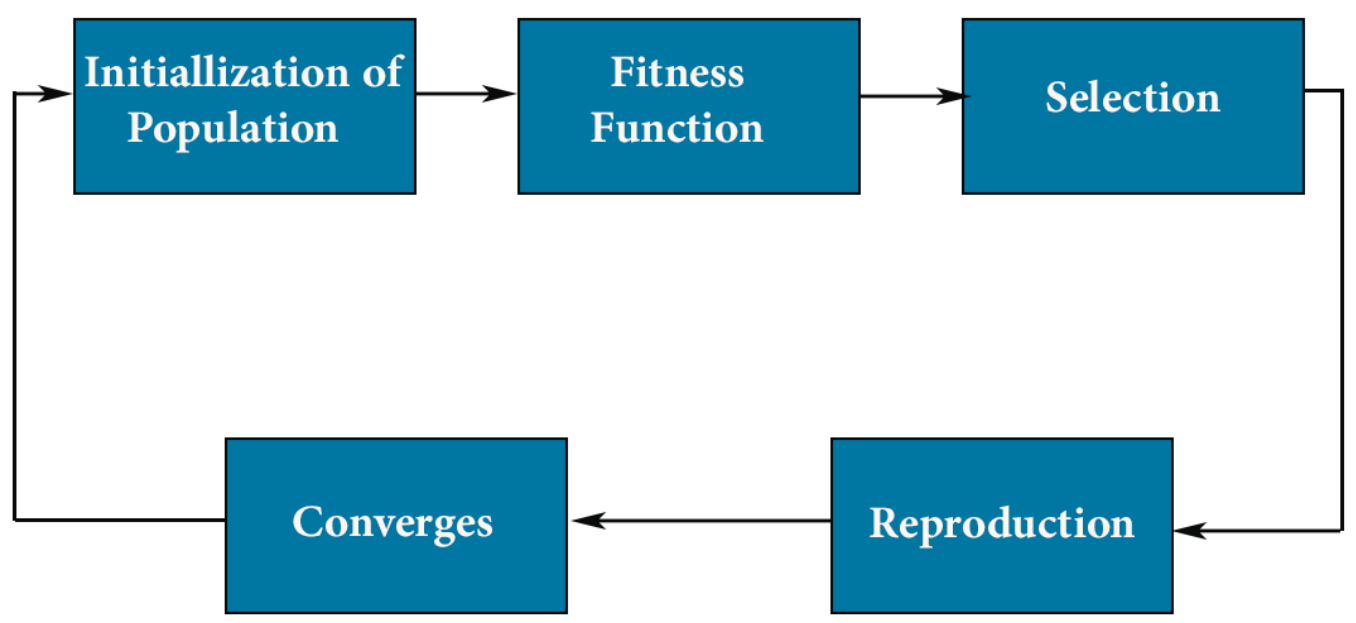

Figure 4. Architecture of the genetic algorithm.

Mohammed and Amirat presented [77] an intelligence-based evolutionary algorithm (GA) for optimizing the EMS and design of a freestanding hybrid microgrid that includes wind, PV, tidal, and batteries. This proposed GA approach was generated to lower the hybrid system's cost. Using the genetic algorithm approach, [78] investigated the energy management of a freestanding hybrid microgrid that included a wind turbine, solar panels, a diesel generator, and a battery. The GA was used to solve size difficulties, reduce costs, and alleviate pollution emission concerns. Furthermore, utilizing HOMER, GA was utilized to solve optimal meet load demand problems in order to increase the relevance of RES.

A summary of recent studies of EMS based on particle swarm optimization is presented in Table 3.

Table 3. A summary of recent studies of EMS based on particle swarm optimization.

\begin{tabular}{|c|c|c|c|}
\hline Reference & System Configuration & EMS Approach & Remarks \\
\hline [62] & Multi agent MG & $\begin{array}{l}\mathrm{PSO} / \mathrm{ACPSO} \text { via Jade } \\
\text { and MATLAB }\end{array}$ & $\begin{array}{l}\text { Author proposed three methods to stabilize the load } \\
\text { curve and compare it with each other. }\end{array}$ \\
\hline [63] & $\begin{array}{l}\text { Solar/Diesel hybrid } \\
\text { Generator }\end{array}$ & PSO via MATLAB & $\begin{array}{l}\text { Author studied two cases of optimal scheduling of } \\
\text { hybrid generator. }\end{array}$ \\
\hline$[64]$ & Grid-connected MGs & PSO via MATLAB & $\begin{array}{c}\text { Author proposed modified algorithm to deal with } \\
\text { cost function and battery charging } \\
\text { discharging modes. }\end{array}$ \\
\hline [65] & DC-DGs & $\begin{array}{l}\text { PSO/SA via } \\
\text { MATLAB/sequential } \\
\text { programming }\end{array}$ & $\begin{array}{l}\text { The researcher proposed master salve strategy to find } \\
\text { the solution of optimal BSS. }\end{array}$ \\
\hline [66] & Hybrid MGs & PSO & $\begin{array}{c}\text { The Research evaluated optimal BESS system to } \\
\text { enhance the performance of MGs. }\end{array}$ \\
\hline
\end{tabular}

\section{Artificial Intelligence Approaches in EMS}

\subsection{Energy Management Based on Neural Networks}

The requirements of modern industries are not fulfilled through conventional control techniques, so it is time to deal with problems with artificial intelligence methods, such as ANN, whose basic structure is shown in Figure 5. The proposed control technique can also handle nonlinear systems [79]. Similarly to human beings, ANNs learn through examples. ANN is designed for specific applications, such as pattern recognition and classification of 
data through a learning process. In a biological system, learning requires adjustments to the synaptic connections between neurons, just like ANN. It has numerous capabilities for complex systems, such as prediction, modeling, and control of performance [80-82].

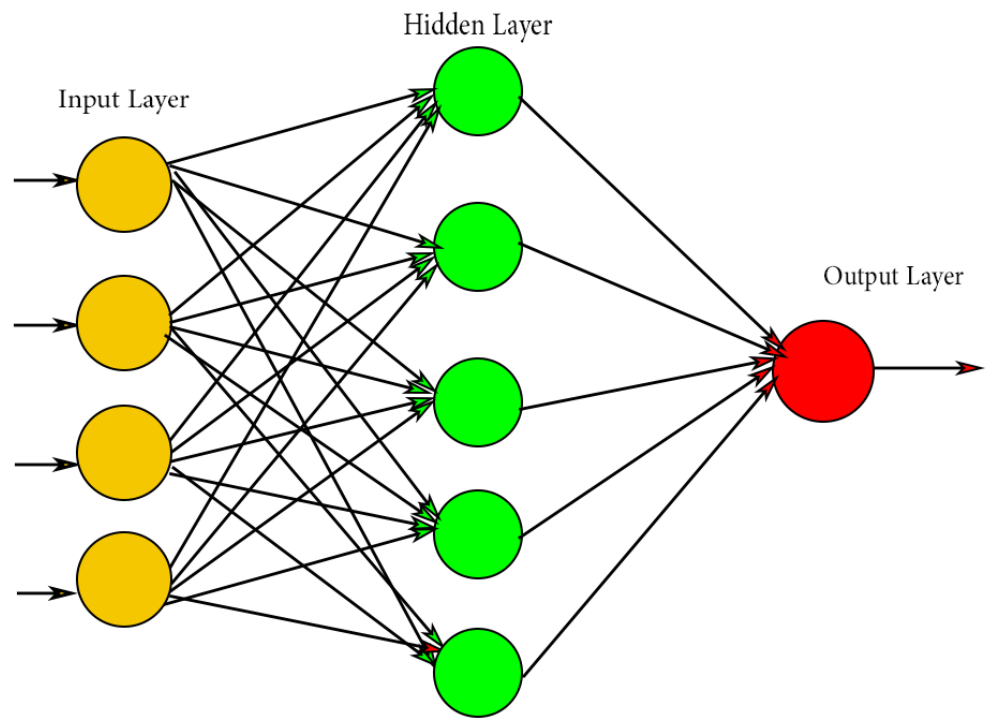

Figure 5. The architecture of an exemplary artificial neural network.

K. Roy and K. K. Mandal [83] presented a cost-effective EM model of a hybrid microgrid including a PV/WT/storage system. In this paper, real-time optimal scheduling of the microgrid was introduced to decrease the cost of electricity production. Using MAT$\mathrm{LAB} /$ Simulink, the author developed a recurrent neural network (RNN) to assess demand response and an ant-lion optimizer (ALO) algorithm to address economic dispatch issues, and the results were compared to some existing methods. Jaganmohan Reddy and Pavan Kumar [84] developed a load forecasting EMS model of a microgrid that predicted short, medium, and long-term forecasts. The artificial neural network (ANN) was used in this study to assess real-time statistical forecasting of microgrids in various situations, such as daily, seasonal, and annual. The Levenberg-Marquardt back propagation algorithm was used to train the layers of the ANN, which enhanced coordination between microgrids in various places. MATLAB/Simulink was used to create this model. Another study [85] suggested a cost-effective EEMS for optimal wind turbine (WT) scheduling, an energy storage system (ESS), and an optimization module in interconnected microgrids. In this study, an artificial neural network (ANN) was developed to anticipate wind speed, and an ESS was utilized to decrease wind turbine fluctuation. Bacterial foraging optimization (MBFO) was used to address multi-objective problems. In terms of economic and environmental efficiency, this study showed that the EEMS can successfully coordinate the power generation of DERs and ESS.

K. Roy and K. Krishna Manda presented [86] a hybrid strategy to reduce the cost of producing renewable energy resources. A hybrid microgrid consisting of a PV/WT/storage system was considered in this paper. The ANN and BFOA techniques were used to control power flow between the sources and the grid. The proposed techniques were implemented via MATLAB/Simulink, and they compared the results with GA and $A B C$ algorithms. In [87], optimized scheduling of a MG solved the uncertainty of wind power/MT/FC/ESS. A probabilistic concept, APCCI, was applied to investigate the problems in the MG. To increase the accuracy of the wind turbine, wavelet decomposition was applied and results were sent to an ANN. The ANN provided optimal scheduling and enhanced the performance of MG. In [88], the authors presented an AI technique to reduce the demand for energy in peak hours and maximize the use of renewable energy sources such as PV/WT. 
ANN and GA were used to provide optimal scheduling and manage the real-time energy demand in the domestic sector.

\subsection{Energy Management Based on Fuzzy Logic}

Many hybrid renewable energy systems have successfully employed fuzzy controllers as energy control and management units (EMU) [89-94]. Many logic values dealing with reality make up fuzzy logic. Fuzzy logic deals with Boolean values, such as 0 and 1 logics, which are both totally true and completely false. Figure 6 depicts the basic architecture of fuzzy logic.

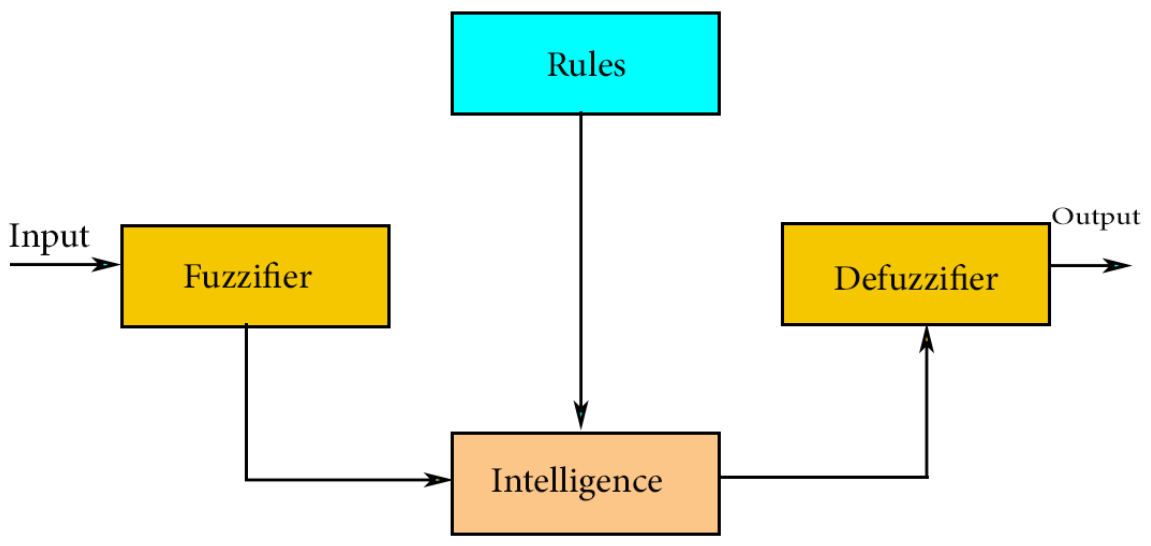

Figure 6. The architecture of fuzzy logic.

I. Abadlia proposed [95] the power management of renewable energy sources (RES) of a standalone hybrid microgrid. In this system, PV/FC/BES and PEMFC are used to ensure the continuous supply of power. Fuzzy logic energy management (FLPMS) was used in this paper to achieve the power management goals. FLPMS maximized the hydrogen production and continuous charging/discharging of the battery to meet the deficit power demands. In [96], the authors presented the energy management of a grid connected microgrid using a renewable energy source. The goals of minimizing the power fluctuations and keeping the battery SOC under a secure limit were achieved by the low complexity fuzzy logic controller.

L. Ciabattoni [97] used the fuzzy logic inference method to create a high-resolution model for household power usage. The aim of this research was to investigate the realworld economic advantages of altering load behavior using a novel fuzzy model and economic impact analysis. In [98], DSM was controlled by a fuzzy controller and a smart home scheduler. Costs and energy usage were minimized via fuzzy logic. The paper [99] describes a microgrid energy management system that incorporates PV/FC/battery with numerous grid-connected and off-grid modes. In the EM unit, fuzzy logic is utilized to identify the appropriate modes of operation for real-time and long-term anticipated energy generation data. Moreover synchronized bus-voltage balance is used to increase microgrid performance. The authors performed energy distribution and cost analysis.

A peak hour energy demand solution for an HVAC residential system was presented in [100]. Two methods were derived in this paper. The first one is supervised fuzzy logic learning (SFLL) to deal with electrical pricing, and the second one is an adaptive fuzzy logic model (AFLM) proposed in order to sense, understand, and adjust to new user preferences. In addition, a "house energy simulator" with an HVAC system, thermostat, and a smart meter was built in MATLAB-GUI to emulate an adjustable residential building. Fuzzy based dynamic EM was presented in [101] to increase the efficiency of a DC microgrid; fuzzy logic was implemented to improve the optimal charging and discharging of HESS. 


\section{EMS Based on Other Approaches}

To improve the power output of each individual source, minimize the cost of energy, or maximize storage systems, several optimization methods are employed in general. The most commonly utilized optimization techniques and algorithms addressed in the literature study are shown in Figure 7, and a comparative analysis of optimization techniques is listed in Table 4.

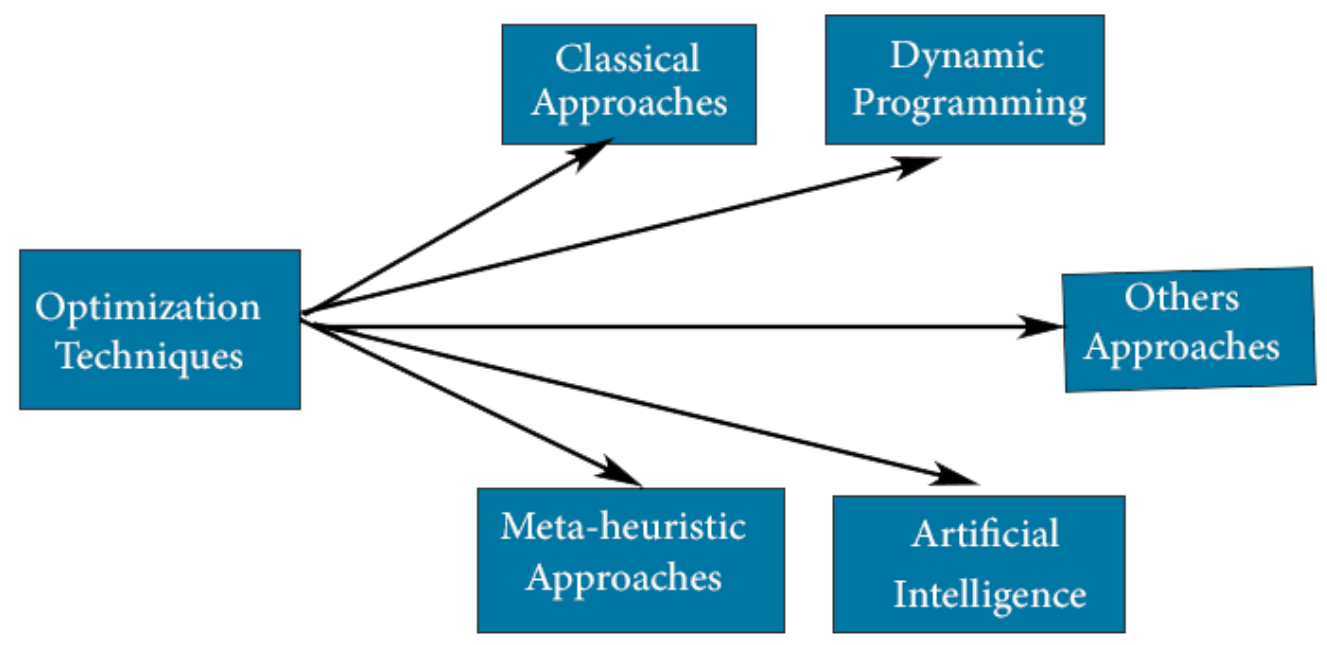

Figure 7. EMS optimization techniques.

Table 4. Comparative analysis of optimization techniques.

\begin{tabular}{|c|c|c|}
\hline Optimization Techniques & Advantage & Disadvantage \\
\hline MILP & $\begin{array}{l}\text { Linear programming (LP) is a quick way to solve } \\
\text { problems because the linear constraints lead to a } \\
\text { convex feasible region, ensuring that the global } \\
\text { optimal solution is achieved in many scenarios. }\end{array}$ & $\begin{array}{l}\text { It shows limited abilities while dealing } \\
\text { with non-differentiateable and } \\
\text { continuous objective functions }\end{array}$ \\
\hline MINLP & $\begin{array}{l}\text { MINLP provides multiple optimal solutions of } \\
\text { complex models which is an edge over } \\
\text { MILP approach. }\end{array}$ & $\begin{array}{l}\text { A large number of iterations are } \\
\text { required (high computational power). }\end{array}$ \\
\hline Dynamic programming (DP) & $\begin{array}{c}\text { It can reduce the problem into sub problems, } \\
\text { optimize each one, and moreover resolve } \\
\text { sequential problems }\end{array}$ & $\begin{array}{l}\text { Due to the large number of recursive } \\
\text { functions, the implementation } \\
\text { is complex }\end{array}$ \\
\hline Genetic algorithms (GA) & $\begin{array}{l}\text { To identify the best solution, population-based } \\
\text { evolutionary algorithms employ operations like } \\
\text { as crossover, mutation, and selection. } \\
\text { An acceptable convergence speed. It is widely } \\
\text { employed in a variety of fields. }\end{array}$ & $\begin{array}{l}\text { Parameters for crossover and mutation, } \\
\text { and population and stopping, must } \\
\text { be defined. }\end{array}$ \\
\hline $\begin{array}{l}\text { Particle swarm optimization } \\
\text { (PSO) }\end{array}$ & $\begin{array}{l}\text { Good results in scattering and } \\
\text { optimization problems. }\end{array}$ & $\begin{array}{l}\text { Complicated computational } \\
\text { requirements. }\end{array}$ \\
\hline Neural Networks & $\begin{array}{l}\text { It is utilized in situations where a quick } \\
\text { evaluation of the learned target function } \\
\text { is necessary. }\end{array}$ & High computational power Required \\
\hline Fuzzy logic (FL) & $\begin{array}{l}\text { To analysis the decision of the system FL } \\
\text { provides best solution. }\end{array}$ & $\begin{array}{l}\text { Don't have the capability of learning } \\
\text { which neural networks have. }\end{array}$ \\
\hline
\end{tabular}

In [102], Roshandel devised an optimization method for finding the best cost-effective design for a stand-alone MG with a lithium battery storage system while taking into account various energy management control methods. To assess the battery's stability and longevity, 
a complex model based on electrochemistry is used to assume the lifetime of lithium batteries. The results of a comparison of optimization techniques for the management of stand-alone MGs were published in reference [103]. Linear programming and genetic algorithms are typically used in this method. The findings show that managing regulated loads can save money by lowering operating costs and increasing the usage of renewable energy sources.

In [104], a series of approaches such as mixed integer programming for energy management optimization and the probabilistic Markov model to reflect PV generation uncertainty were used to study the development and MG optimization. A linear model was used to calculate the MG's lifetime. The authors of [105] presented an energy management system for a hybrid system that included wind, PV, and diesel. The service works both on and off the grid. Transitions between micro and utility grids are also controlled by a mechanism built within the inverter.

There are other factors that are not included in this paper that are required to identify the most suitable communication systems for microgrids, focusing on overall microgrid operations such as the transient response of distributed resources. When it comes to sensitive data transfer, such as protective relays, switches, and fault detectors, it is necessary to improve dependability and minimize delay problems. It is also important to optimize communications technology in order to improve control system functions such as reactive power regulation and power quality improvement control [32].

Moreover, in [106] a microgrid energy management system, research comparing WiFi-based servers against wired connectivity was carried out. The wireless infrastructure provides a dependable, easy-to-build, and scalable infrastructure for a small-scale microgrid control system, although it has larger communication delays than cable LAN. Data from wireless communications experiments show that $\mathrm{Wi}-\mathrm{Fi}$ is a viable choice for WAN infrastructure [107]. The energy efficiency of Li-ion batteries as energy storage devices in microgrids is being studied. The energy efficiency of a Li-ion battery is determined by its energy efficiency during charging and discharging scenarios [108,109].

\section{Conclusions and Future Trends}

Distributed energy resources, demand response, electric cars, and local controllers are the main building blocks of microgrids to be applied for smart cities. A central controller and communication devices are used to manage energy in a microgrid. This article presented a critical and comprehensive review of microgrid energy management issues and possible solutions. The fundamental goal of the EMS is to provide grid-connected and off-grid microgrids with minimal operating costs, optimal scheduling, and uninterrupted power delivery. As a result, the microgrid energy management framework is a multiobjective subject that addresses economic, technological, and environmental concerns of the smart city.

Various optimization approaches were explored in this study to find optimal solutions for microgrid operators' coordination. The assessment was mostly based on smart city requirements, particularly in terms of electricity consumption and management. Through the use of a variety of effective methods, these strategies explore alternatives, opportunities, and challenges to achieve energy management objectives. Then using a computer system, each microgrid operator receives the most cost-effective, least interrupted in terms of power flow, solution.

These approaches are chosen on the basis of their adequacy, practicability, and usability for optimal growth of microgrids. MG EMS also takes into account environmental concerns of conventional generators, the life expectancy of batteries, efficient DR integration, power loss and robustness, and the privacy of the customer. Some of these objectives have been the subject of studies. To achieve efficient operation of microgrids, there is still much work to be done, including improving customer privacy issues, analyzing the reliability of efficient communications systems, and managing costs. From the perspective of the energy system, effective energy management for lithium batteries is necessary. Thus, more 
accurate degradation models to accurately estimate battery lifespan in real-time operating scenarios need to be created.

Author Contributions: Conceptualization and software, M.S.S., M.A. and M.M.H.; methodology, M.S.S., M.A., M.M.H. and R.A.; writing—original draft preparation, M.A., R.A. and M.M.H.; writingreview and editing, M.H.N., M.S.K., S.R. and R.A.; data curation, M.M.H. and S.R. All authors have read and agreed to the published version of the manuscript.

Funding: This research received no external funding.

Institutional Review Board Statement: Not applicable.

Informed Consent Statement: Not applicable.

Data Availability Statement: Data is contained within the article.

Conflicts of Interest: The authors declare no conflict of interest.

\section{References}

1. Batty, M.; Axhausen, K.W.; Giannotti, F.; Pozdnoukhov, A.; Bazzani, A.; Wachowicz, M.; Ouzounis, G.; Portugali, Y. Smart cities of the future. Eur. Phys. J. Spec. Top. 2012, 214, 481-518. [CrossRef]

2. Ma, T.; Wu, J.; Hao, L.; Lee, W.J.; Yan, H.; Li, D. The optimal structure planning and energy management strategies of smart multi energy systems. Energy 2008, 160, 122-141. [CrossRef]

3. Hussain, M.M.; Javed, W.; Akram, R.; Javed, T.; Razaq, A.; Siddique, M. Distributed energy management analysis for microgrids. In Proceedings of the 56th International Universities Power Engineering Conference, Middlesbrough, UK, 31 August-3 September 2021.

4. Amponsah, N.Y.; Troldborg, M.; Kington, B.; Aalders, I.; Hough, R.L. Greenhouse gas emissions from renewable energy sources: A review of lifecycle considerations. Renew. Sustain. Energy Rev. 2014, 39, 461-475. [CrossRef]

5. Sen, S.; Ganguly, S. Opportunities, barriers and issues with renewable energy development-A discussion. Renew. Sustain. Energy Rev. 2017, 69, 1170-1181. [CrossRef]

6. Momete, D.C. Analysis of the Potential of Clean Energy Deployment in the European Union. IEEE Access 2018, 6, 54811-54822. [CrossRef]

7. Lee, J.; Shepley, M.M.C. Benefits of solar photovoltaic systems for low-income families in social housing of Korea: Renewable energy applications as solutions to energy poverty. J. Build. Eng. 2020, 28, 101016. [CrossRef]

8. Saleh, A.M.; Haris, A.; Ahmad, N. Towards a UTAUT-based model for the intention to use solar water heaters by Libyan households. Int. J. Energy Econ. Policy 2014, 4, 26-31.

9. Parhizi, S.; Lotfi, H.; Khodaei, A.; Bahramirad, S. State of the art in research on microgrids: A review. IEEE Access 2015, 3, 890-925. [CrossRef]

10. Caspary, G. Gauging the future competitiveness of renewable energy in Colombia. Energy Econ. 2009, 31, 443-449. [CrossRef]

11. Panwar, N.L.; Kaushik, S.C.; Kothari, S. Role of renewable energy sources in environmental protection: A review. Renew. Sustain. Energy Rev. 2011, 15, 1513-1524. [CrossRef]

12. Coelho, V.N.; Coelho, I.M.; Coelho, B.N.; de Oliveira, G.C.; Barbosa, A.C.; Pereira, L.; de Freitas, A.; Santos, H.G.; Ochi, L.S.;Guimarães, F.G. A communitarian microgrid storage planning system inside the scope of a smart city. Appl. Energy 2017, 201, 371-381. [CrossRef]

13. Beheshtaein, S.; Cuzner, R.M.; Forouzesh, M.; Savaghebi, M.; Guerrero, J.M. DC Microgrid Protection: A Comprehensive Review. IEEE J. Emerg. Sel. Top. Power Electron. 2019. [CrossRef]

14. Hussain, M.M.; Siddique, M.; Raees, M.; Nouman, A.; Javed, W.; Razaq, A. Power management through smart grids and advance metering infrastructure. In Proceedings of the 6th IEEE International Energy Conference, Gammarth, Tunisia, 28 September-1 October 2020; pp. 767-772.

15. Cagnano, A.; De Tuglie, E.; Mancarella, P. Microgrids: Overview and guidelines for practical implementations and operation. Appl. Energy 2020, 258, 114039. [CrossRef]

16. Hossain, E.; Kabalci, E.; Bayindir, R.; Perez, R. Microgrid testbeds around the world: State of art. Energy Convers. Manag. 2014, 86, 132-153. [CrossRef]

17. Chen, Y.H.; Lu, S.Y.; Chang, Y.R.; Lee, T.T.; Hu, M.C. Economic analysis and optimal energy management models for microgrid systems: A case study in Taiwan. Appl. Energy 2013, 103, 145-154. [CrossRef]

18. Thirugnanam, K.; Kerk, S.K.; Yuen, C.; Liu, N.; Zhang, M. Energy Management for Renewable Microgrid in Reducing Diesel Generators Usage with Multiple Types of Battery. IEEE Trans. Ind. Electron. 2018, 65, 6772-6786. [CrossRef]

19. Yang, N.; Paire, D.; Gao, F.; Miraoui, A. Power management strategies for microgrid-A short review. In Proceedings of the Conference Record-IAS Annual Meeting (IEEE Industry Applications Society), Lake Buena Vista, FL, USA, 6-11 October 2013; pp. 1-9. [CrossRef] 
20. Faccio, M.; Gamberi, M.; Bortolini, M.; Nedaei, M. State-of-art review of the optimization methods to design the configuration of hybrid renewable energy systems (HRESs). Front. Energy 2018, 12, 591-622. [CrossRef]

21. Cristóbal-Monreal, I.R.; Dufo-López, R. Optimisation of photovoltaic-diesel-battery stand-alone systems minimising system weight. Energy Convers. Manag. 2016, 119, 279-288. [CrossRef]

22. Vera, Y.E.G.; Dufo-López, R.; Bernal-Agustín, J.L. Energy management in microgrids with renewable energy sources: A literature review. Appl. Sci. 2019, 9, 3854. [CrossRef]

23. Razaq, A.; Hussain, M.M.; Javed, W.; Javed, T.; Memon, Z.A. Detection and prevention of denial-of-service in cloud-based smart grid. In Proceedings of the 10th International Conference on Smart Cities and Green ICT Systems, Prague, Czech Republic, 28-30 April 2021; pp. 172-179.

24. Liu, N.; Tang, Q.; Zhang, J.; Fan, W.; Liu, J. A hybrid forecasting model with parameter optimization for short-term load forecasting of micro-grids. Appl. Energy 2014, 129, 336-345. [CrossRef]

25. Shi, W.; Lee, E.K.; Yao, D.; Huang, R.; Chu, C.C.; Gadh, R. Evaluating microgrid management and control with an implementable energy management system. In Proceedings of the 2014 IEEE International Conference on Smart Grid Communications, SmartGridComm 2014, Venice, Italy, 3-6 November 2014; pp. 272-277. [CrossRef]

26. John, T.; Lam, S.P. Voltage and frequency control during microgrid islanding in a multi-area multi-microgrid system. IET Gener. Transm. Distrib. 2017, 11, 1502-1512. [CrossRef]

27. Silvente, J.; Kopanos, G.M.; Pistikopoulos, E.N.; Espuña, A. A rolling horizon optimization framework for the simultaneous energy supply and demand planning in microgrids. Appl. Energy 2015, 155, 485-501. [CrossRef]

28. Zeng, P.; Li, H.; He, H.; Li, S. Dynamic Energy Management of a Microgrid Using Approximate Dynamic Programming and Deep Recurrent Neural Network Learning. IEEE Trans. Smart Grid. 2019, 10, 4435-4445. [CrossRef]

29. Dou, C.; Lv, M.; Zhao, T.; Ji, Y.; Li, H. Decentralised coordinated control of microgrid based on multi-agent system. IET Gener. Transm. Distrib. 2015, 9, 2474-2484. [CrossRef]

30. Razaq, A.; Hussain, M.M.; Siddique, M. Smart grid simulation based on high level architecture. In Proceedings of the 9th European Conference on Renewable Energy Systems, Istanbul, Turkey, 21-23 April 2021.

31. Marzb, M.; Ghadimi, M.; Sumper, A.; Domínguez-García, J.L. Experimental validation of a real-time energy management system using multi-period gravitational search algorithm for microgrids in islanded mode. Appl. Energy 2014, 128, 164-174. [CrossRef]

32. Bani-Ahmed, A.; Weber, L.; Nasiri, A.; Hosseini, H. Microgrid communications: State of the art and future trends. In Proceedings of the 3rd International Conference on Renewable Energy Research and Applications, ICRERA 2014, Milwaukee, WI, USA, 19-22 October 2014; pp. 780-785. [CrossRef]

33. Chen, C.; Duan, S.; Cai, T.; Liu, B.; Hu, G. Smart energy management system for optimal microgrid economic operation. IET Renew. Power Gener. 2011, 5, 258-267. [CrossRef]

34. Palma-Behnke, R.; Ortiz, D.; Reyes, L.; Jiménez-Estévez, G.; Garrido, N. A social SCADA approach for a renewable based microgrid-The Huatacondo project. IEEE Power Energy Soc. Gen. Meet. 2011. [CrossRef]

35. Lazar, E.; Etz, R.; Petreus, D.; Patarau, T.; Ciocan, I. SCADA development for an islanded microgrid. In Proceedings of the 2015 IEEE 21st International Symposium for Design and Technology in Electronic Packaging, SIITME 2015, Brasov, Romania, 22-25 October 2015; pp. 147-150. [CrossRef]

36. Bhattacharjee, S.; Acharya, S. PV-wind hybrid power option for a low wind topography. Energy Convers. Manag. 2015, 89, 942-954. [CrossRef]

37. Dufo-López, R.; Bernal-Agustín, J.L.; Mendoza, F. Design and economical analysis of hybrid PV-wind systems connected to the grid for the intermittent production of hydrogen. Energy Policy 2009, 37, 3082-3095. [CrossRef]

38. Tina, G.M.; Gagliano, S. Probabilistic modelling of hybrid solar/wind power system with solar tracking system. Renew. Energy 2011, 36, 1719-1727. [CrossRef]

39. Kolhe, P.; Bitzer, B.; Chowdhury, S.P.; Chowdhury, S. Hybrid power system model and TELELAB. In Proceedings of the Universities Power Engineering Conference, Middlesex, UK, 4-7 September 2012. [CrossRef]

40. Torreglosa, J.P.; García, P.; Fernández, L.M.; Jurado, F. Energy dispatching based on predictive controller of an off-grid wind turbine/photovoltaic/hydrogen/battery hybrid system. Renew. Energy 2015, 74, 326-336. [CrossRef]

41. Liu, K.; El-Gohary, N. Ontology-based data integration for supporting big bridge data analytics. In Proceedings of the 6th CSCE-CRC International Construction Specialty Conference 2017-Held as Part of the Canadian Society for Civil Engineering Annual Conference and General Meeting, Vancouver, Canada, 31 May-3 June 2017; Volume 2, pp. $1089-1098$.

42. de Azevedo, Dias, C.L.; Branco, D.A.C.; Arouca, M.C.; Legey, L.F.L. Performance estimation of photovoltaic technologies in Brazil. Renew. Energy 2017, 114, 367-375. [CrossRef]

43. Dursun, E.; Kilic, O. Comparative Evaluation of Different Power Management Strategies of a Stand-alone PV/Wind/PEMFC Hybrid Power System. Int. J. Electr. Power Energy Syst. 2012, 34, 81-89. [CrossRef]

44. Ahmad, J.; Imran, M.; Khalid, A.; Iqbal, W.; Ashraf, S.R.; Adnan, M.; Ali, S.F.; Khokhar, K.S. Techno economic analysis of a wind-photovoltaic-biomass hybrid renewable energy system for rural electrification: A case study of Kallar Kahar. Energy 2018, 148, 208-234. [CrossRef]

45. Simonetti, R.; Moretti, L.; Molinaroli, L.; Manzolini, G. Energetic and economic optimization of the yearly performance of three different solar assisted heat pump systems using a mixed integer linear programming algorithm. Energy Convers. Manag. 2020, 206, 112446. [CrossRef] 
46. Moazeni, F.; Khazaei, J. Optimal operation of water-energy microgrids; a mixed integer linear programming formulation. J. Clean. Prod. 2020, 275, 122776. [CrossRef]

47. Behzadi, M.S.; Niasati, M. Comparative performance analysis of a hybrid PV/FC/battery stand-alone system using different power management strategies and sizing approaches. Int. J. Hydrogen Energy 2015, 40, 538-548. [CrossRef]

48. Nemati, M.; Braun, M.; Tenbohlen, S. Optimization of unit commitment and economic dispatch in microgrids based on genetic algorithm and mixed integer linear programming. Appl. Energy 2018, 210, 944-963. [CrossRef]

49. Sukumar, S.; Mokhlis, H.; Mekhilef, S.; Naidu, K.; Karimi, M. Mix-mode energy management strategy and battery sizing for economic operation of grid-tied microgrid. Energy 2017, 118, 1322-1333. [CrossRef]

50. Anglani, N.; Oriti, G.; Colombini, M. Optimized energy management system to reduce fuel consumption in remote military microgrids. IEEE Trans. Ind. Appl. 2017, 53, 5777-5785. [CrossRef]

51. Helal, S.A.; Hanna, M.O.; Najee, R.J.; Shaaban, M.F.; Osman, A.H.; Hassan, M.S. Energy Management System for Smart Hybrid AC/DC Microgrids in Remote Communities. Electr. Power Compon. Syst. 2019, 47, 1012-1024. 2019.1629512. [CrossRef]

52. Balderrama, S.; Lombardi, F.; Riva, F.; Canedo, W.; Colombo, E.; Quoilin, S. A two-stage linear programming optimization framework for isolated hybrid microgrids in a rural context: The case study of the "El Espino" community. Energy 2019, 188, 116073. [CrossRef]

53. Merabet, A.; Tawfique, Ahmed K.; Ibrahim, H.; Beguenane, R.; Ghias, A.M.Y.M. Energy Management and Control System for Laboratory Scale Microgrid Based Wind-PV-Battery. IEEE Trans. Sustain. Energy 2017, 8, 145-154. [CrossRef]

54. Jafari, M.; Malekjamshidi, Z. Optimal energy management of a residential-based hybrid renewable energy system using rule-based real-time control and 2D dynamic programming optimization method. Renew. Energy 2020, 146, 254-266. [CrossRef]

55. Wang, X.; Ji, Y.; Wang, J.; Wang, Y.; Qi, L. Optimal energy management of microgrid based on multi-parameter dynamic programming. Int. J. Distrib. Sens. Netw. 2020, 16. [CrossRef]

56. Shuai, H.; Fang, J.; Ai, X.; Wen, J.; He, H. Optimal Real-Time Operation Strategy for Microgrid: An ADP-Based Stochastic Nonlinear Optimization Approach. IEEE Trans. Sustain. Energy 2019, 10, 931-942. [CrossRef]

57. Du, K.L.; Swamy, M.N.S. Search and optimization by metaheuristics: Techniques and algorithms inspired by nature. Search Optim. Metaheuristics Tech. Algorithms Inspired Nat. 2016, 1-434. [CrossRef]

58. Chopard, B.; Tomassini, M. Particle Swarm Optimization. An Introduction to Metaheuristics for Optimization. Nat. Comput. Ser. 2018, 23, 145-156. [CrossRef]

59. Pedersen, M.E.H.; Chipperfield, A.J. Simplifying Particle Swarm Optimization. Appl. Soft Comput. J. 2010, 10, 618-628. [CrossRef]

60. Zhan, Z.H.; Zhang, J.; Li, Y.; Shi, Y.H. Orthogonal learning particle swarm optimization. IEEE Trans. Evol. Comput. 2011, 15, 832-847. [CrossRef]

61. Du, W.B.; Gao, Y.; Liu, C.; Zheng, Z.; Wang, Z. Adequate is better: Particle swarm optimization with limited-information. Appl. Math. Comput. 2015, 268, 832-838. [CrossRef]

62. Li, C.; Jia, X.; Zhou, Y.; Li, X. A microgrids energy management model based on multi-agent system using adaptive weight and chaotic search particle swarm optimization considering demand response. J. Clean. Prod. 2020, 262, 121247. [CrossRef]

63. Yang, R.; Yuan, Y.; Ying, R.; Shen, B.; Long, T. A novel energy management strategy for a ship's hybrid solar energy generation system using a particle swarm optimization algorithm. Energies 2020, 13, 1380. [CrossRef]

64. Hossain, M.A.; Pota, H.R.; Squartini, S.; Abdou, A.F. Modified PSO algorithm for real-time energy management in grid-connected microgrids. Renew. Energy 2019, 136, 746-757. [CrossRef]

65. Grisales-Noreña, L.F.; Montoya, O.D.; Ramos-Paja, C.A. An energy management system for optimal operation of BSS in DC distributed generation environments based on a parallel PSO algorithm. J. Energy Storage 2020, 29, 101488. [CrossRef]

66. Kerdphol, T.; Qudaih, Y.; Mitani, Y. Optimum battery energy storage system using PSO considering dynamic demand response for microgrids. Int. J. Electr. Power Energy Syst. 2016, 83, 58-66. [CrossRef]

67. Wang, C.; Colson, C.M.; Nehrir, M.H.; Li, J. Power management of a stand-alone hybrid wind-microturbine distributed generation system. IEEE Power Electron. Mach. Wind. Appl. 2009. [CrossRef]

68. Litchy, A.J.; Nehrir, M.H. Real-time energy management of an islanded microgrid using multi-objective Particle Swarm Optimization. IEEE Power Energy Soc. Gen. Meet. 2014, 1-5. [CrossRef]

69. Mirjalili, S. Genetic algorithm. Stud. Comput. Intell. 2019, 780, 43-55. [CrossRef]

70. Lingaraj, H. A Study on Genetic Algorithms and its Applications. Int. J. Comput. Sci. Eng. 2016, 4, 139-143.

71. Hinçal, O.; Altan-Sakarya, A.B.; Ger, A.M. Optimization of Multireservoir Systems by Genetic Algorithm. Water Resour. Manag. 2011, 25, 1465-1487. [CrossRef]

72. Yu, B.; Yang, Z.; Yao, J. Genetic algorithm for bus frequency optimization. J. Transp. Eng. 2010, 136, 576-583. [CrossRef]

73. Jianjun Hu, Y.S. and Q.X. The theory and application of Genetic Algorithm. In Proceedings of the 2010 International Conference on Computer and Communication Technologies in Agriculture Engineering, Beijing, China, 16-19 September 2014; Volume 28 , p. 297.

74. Bhoskar, T.; Kulkarni, O.K.; Kulkarni, N.K.; Patekar, S.L.; Kakikar, G.M.N.; edkar, V.M. Genetic Algorithm and its Applications to Mechanical Engineering: A Review. Mater. Today Proc. 2015, 2, 2624-2630. [CrossRef]

75. Dao, S.D.; Abhary, K.; Marian, R. An innovative framework for designing genetic algorithm structures. Expert Syst. Appl. 2017, 90, 196-208. [CrossRef] 
76. Shukla, A.P.; Ey, H.M.; Mehrotra, D. Comparative review of selection techniques in genetic algorithm. In Proceedings of the 2015 1st International Conference on Futuristic Trends in Computational Analysis and Knowledge Management, ABLAZE 2015, Greater Noida, India, 25-27 February 2015; pp. 515-519. [CrossRef]

77. Mohammed, O.H.; Amirat, Y.; Benbouzid, M. Economical evaluation and optimal energy management of a stand-alone hybrid energy system handling in genetic algorithm strategies. Electronics 2018, 7, 233. [CrossRef]

78. Zhao, B.; Zhang, X.; Li, P.; Wang, K.; Xue, M.; Wang, C. Optimal sizing, operating strategy and operational experience of a stand-alone microgrid on Dongfushan Island. Appl. Energy 2014, 113, 1656-1666. [CrossRef]

79. Unny, M.S.H.; Hossain, E.; Ahmed, M.; Un-Noor, F. Artificial Neural Network Based Dynamic Voltage Restorer for Improvement of Power Quality. In Proceedings of the 2018 IEEE Energy Conversion Congress and Exposition, ECCE 2018, Portland, OR, USA, 23-27 September 2018; pp. 5565-5572. [CrossRef]

80. Marino, D.L.; Amarasinghe, K.; Manic, M. Building energy load forecasting using Deep Neural Networks. In Proceedings of the IECON Proceedings (Industrial Electronics Conference), Florence, Italy, 24-27 October 2016; pp. 7046-7051. [CrossRef]

81. Benedetti, M.; Cesarotti, V.; Introna, V.; Serranti, J. Energy consumption control automation using Artificial Neural Networks and adaptive algorithms: Proposal of a new methodology and case study. Appl. Energy 2016, 165, 60-71. [CrossRef]

82. Amarasinghe, K.; Marino, D.L.; Manic, M. Deep neural networks for energy load forecasting. IEEE Int. Symp. Ind. Electron. 2017, 1483-1488. [CrossRef]

83. Roy, K.; Mandal, K.K.; Mandal, A.C. Ant-Lion Optimizer algorithm and recurrent neural network for energy management of micro grid connected system. Energy 2019, 167, 402-416. [CrossRef]

84. Reddy, Y.J.; Kumar, Y.P.; Kumar, V.S.; Raju, K.P. Distributed ANNs in a layered architecture for energy management and maintenance scheduling of renewable energy HPS microgrids. In Proceedings of the 2012 International Conference on Advances in Power Conversion and Energy Technologies, APCET 2012, Mylavaram, India, 2-4 August 2012. [CrossRef]

85. Motevasel, M.; Seifi, A.R. Expert energy management of a micro-grid considering wind energy uncertainty. Energy Convers. Manag. 2014, 83, 58-72. [CrossRef]

86. Roy, K.; Mandal, K.K.; Mandal, A.C.; Patra, S.N. Analysis of energy management in micro grid-A hybrid BFOA and ANN approach. Renew. Sustain. Energy Rev. 2018, 82, 4296-4308. [CrossRef]

87. Sarshar, J.; Moosapour, S.S.; Joorabian, M. Multi-objective energy management of a micro-grid considering uncertainty in wind power forecasting. Energy 2017, 139, 680-693. [CrossRef]

88. Yuce, B.; Rezgui, Y.; Mourshed, M. ANN-GA smart appliance scheduling for optimised energy management in the domestic sector. Energy Build. 2016, 111, 311-325. [CrossRef]

89. Mardani, M.M.; Khooban, M.H.; Masoudian, A.; Dragicevic, T. Model Predictive Control of DC-DC Converters to Mitigate the Effects of Pulsed Power Loads in Naval DC Microgrids. IEEE Trans. Ind. Electron. 2019, 66, 5676-5685. [CrossRef]

90. Arcos-Aviles, D.; Sotomayor, D.; Proano, J.L.; Guinjoan, F.; Marietta, M.P.; Pascual, J.; Marroyo, L.; Sanchis, P. Model Predictive Control of DC-DC Converters to Mitigate the Effects of Pulsed Power Loads in Naval DC Microgrids. IEEE Int. Symp. Ind. Electron. 2017, 99-105. [CrossRef]

91. Lagorse, J.; Simoes, M.G.; Miraoui, A. A multiagent fuzzy-logic-based energy management of hybrid systems. IEEE Trans. Ind. Appl. 2009, 45, 2123-2129. [CrossRef]

92. Li, S.G.; Sharkh, S.M.; Walsh, F.C.; Zhang, C.N. Energy and battery management of a plug-in series hybrid electric vehicle using fuzzy logic. IEEE Trans. Veh. Technol. 2011, 60, 3571-3585. [CrossRef]

93. Marzougui, H.; Kadri, A.; Amari, M.; Bacha, F. Improvement of energy management algorithm for fuel cell electrical vehicle with fuzzy logic. In Proceedings of the 18th International Conference on Sciences and Techniques of Automatic Control and Computer Engineering, STA 2017-Proceedings, Monastir, Tunisia, 21-23 December 2017; pp. 212-217. [CrossRef]

94. Yin, H.; Zhou, W.; Li, M.; Ma, C.; Zhao, C. An adaptive fuzzy logic-based energy management strategy on battery/ultracapacitor hybrid electric vehicles. IEEE Trans. Transp. Electrif. 2016, 2, 300-311. [CrossRef]

95. Abadlia, I.; Bahi, T.; Bouzeria, H. Energy management strategy based on fuzzy logic for compound RES/ESS used in stand-alone application. Int. J. Hydrogen Energy 2016, 41, 16705-16717. [CrossRef]

96. Arcos-Aviles, D.; Pascual, J.; Marroyo, L.; Sanchis, P.; Guinjoan, F. Fuzzy logic-based energy management system design for residential grid-connected microgrids. IEEE Trans. Smart Grid 2018, 9, 530-543. [CrossRef]

97. Ciabattoni, L.; Ferracuti, F.; Grisostomi, M.; Ippoliti, G.; Longhi, S. Fuzzy logic based economical analysis of photovoltaic energy management. Neurocomputing 2015, 170, 296-305. [CrossRef]

98. Khalid, R.; Javaid, N.; Rahim, M.H.; Aslam, S.; Sher, A. Fuzzy energy management controller and scheduler for smart homes. Sustain. Comput. Inform. Syst. 2019, 21, 103-118. [CrossRef]

99. Jafari, M.; Malekjamshidi, Z.; Lu, D.D.C.; Zhu, J. Development of a Fuzzy-Logic-Based Energy Management System for a Multiport Multioperation Mode Residential Smart Microgrid. IEEE Trans. Power Electron. 2019, 34, 3283-3301. [CrossRef]

100. Keshtkar, A.; Arzanpour, S. An adaptive fuzzy logic system for residential energy management in smart grid environments. Appl. Energy 2017, 186, 68-81. [CrossRef]

101. Mathews, M.A.; Rajeev, T. Fuzzy Based Management of Hybrid Energy Storage System for Improved Dynamic Response of DC Microgrid. In Proceedings of the 2020 IEEE International Conference on Power Electronics, Smart Grid and Renewable Energy, PESGRE 2020, Cochin, India, 2-4 January 2020; pp. 1-6. [CrossRef] 
102. Astaneh, M.; Roshandel, R.; Dufo-lópez, R.; Bernal-agustín, J.L. A novel framework for optimization of size and control strategy of lithium-ion battery based off-grid renewable energy systems. Energy Convers. Manag. 2018, 175, 99-111. [CrossRef]

103. Neves, D.; Pina, A.; Silva, C.A. Comparison of different demand response optimization goals on an isolated microgrid. Sustain. Energy Technol. Assess. 2018, 30, 209-215. [CrossRef]

104. Yan, B.; Luh, P.B.; Warner, G.; Zhang, P.; Member, S. Operation and Design Optimization of Microgrids with Renewables. IEEE Trans. Autom. Sci. Eng. 2017, 14, 1-13. https://DOI:10.1109/TASE.2016.2645761. [CrossRef]

105. Basaran, K.; Cetin, N.S.; Borekci, S. Energy Management for On-Grid and Off-Grid Wind/PV and Battery Hybrid Systems. IET Renew. Power Gener. 2017, 11, 642-649. [CrossRef]

106. Siow, L.K.; Thus, P.L.; Gooi, H.B.; Luo, F.L.; Gajanayake, C.J.; Vo, Q.N. Wi-Fi based server in microgrid energy management system. In Proceedings of the IEEE Region 10 Annual International Conference, TENCON, Singapore, 23-26 January 2009; pp. $1-5$.

107. Stanciulescu, G.; Farhangi, H.; Palizban, A.; Stanchev, N. Communication technologies for BCIT Smart Microgrid. In Proceedings of the 2012 IEEE PES Innovative Smart Grid Technologies, ISGT 2012, Washington, DC, USA, 16-20 January 2012 ; pp. 1-7.

108. Li, K.; Tseng, K.J. Energy efficiency of lithium-ion battery used as energy storage devices in micro-grid. In Proceedings of the IECON 2015-41st Annual Conference of the IEEE Industrial Electronics Society, Yokohama, Japan, 9-12 November 2015; pp. 5235-5240.

109. Morstyn, T.; Hredzak, B.; Agelidis, V.G. Model Predictive Control for Distributed Microgrid Battery Energy Storage Systems. IEEE Trans. Control. Syst. Technol. 2017, 26, 1107-1114. [CrossRef] 